\title{
PSYCHOLOGICAL AND PEDAGOGICAL FACTORS OF GENDER SOCIALIZATION OF THE PRESCHOOLERS IN UKRAINE
}

\section{Kikinezhdi O. M., Vasylkevych Ya. Z.}

\section{INTRODUCTION}

The actuality of the research is determined by the social need in the identification of psychological and pedagogical factors of gender socialization of preschoolers, the need to study the internal mechanisms of identification of the individual with certain models of gender behavior, democratization of social life, the establishment of egalitarian values in the New Ukrainian school.

Gender and age identification as acceptance of the role of representative of one's gender becomes rather important in the preschool age, since this very age is considered to be important period of "tying the most important knots" of a growing personality. The formation of clear and irreversible representation of "The Boy Self"/"The Girl Self" is observed in such personality. Two types of socialization mechanisms are involved in its formation - gender typization, which is determined by the context of cultural environment and individualization, which has multiple variability and depends on the specific conditions of the life of each child (S. Bem, T. Hovorun, M. Kimmel, I. Kon, V. Kravets, J.-Sh. Hyde, C. Martin, W. Mischel).

The analysis of the domestic and foreign psychological literature on this issue shows the diversity and ambiguity of interpretations of mechanisms of influence on the gender consciousness and self-consciousness formation of a child, in particular, identification with parents and peers (Z. Freud), system of rewards and punishment (A. Bandura), addressing prescriptions to a child and reinforcing gender-specific behavior (E. Maccobby, C. Jacklin), activity of a child him/herself in developing gender roles, and gender self-categorization (L. Kohlberg, J. Pleck, D. Ullian), regarding the fact that the development of gender identity is identical to the stages of cognitive development of a child by J. Piaget. Evaluation by adults, and later peers, of the child's behavior regarding gender compliance or non-compliance significantly influences self-esteem of a person as a gender representative (J. Kolominsky, I. Kon). Gender identity as a result of the processing of information is related to the awareness and understanding of the growing personality of male and female. In all approaches to gender identity, cultural and social factors are important, but parents play a special role in this process.

Understanding by a child him/herself as "me-boy" or "me-girl" contributes to the launch of psychological mechanisms that affect the qualities and attitudes 
of others and help to "build up" into the structure of the personality, and also accompany the implementation of other mechanisms: identification, imitation, encouragement, punishment, suggestion, sensual cognition, empathy, reflection, conformality.

Despite the obvious "openness" of the applied aspect of the problem of gender socialization, it has a considerable inner layer, because it covers many unexplained psychological mechanisms of personal development. The specificity of distinguishing age patterns of acquiring gender behavior of a child, internalization of gender orientations in the process of learning the values of society is an important area of psychological research, but today it remains insufficiently studied, which has determined the purpose of the article to identify the specificity of gender socialization of a child; to empirically study gender representations of preschoolers in the process of socialization in micro-, mesoand macro-environments.

\section{The analysis of recent research and publications}

Theoretical background of the problem analysis of the gender role socialization and identification formed conceptual approaches of genetic, age and pedagogical psychology regarding patterns of personality development, its motivational and need sphere, which are found in the scientific works of H. Ball, I. Bekh, M. Boryshevskyi, V. Haydenko, T. Hovorun, L. Dolynska, E. Erikson, I. Kon, H. Kostiuk, V. Kotyrlo, Y. Kolominsky, U. Kuzmenko, S. Ladyvir, S. Maksimenko, R. Pavelkiv, T. Pirozhenko, Y. Prykhodko, T. Tytarenko, P. Chamata and other scientists.

The category of gender was considered in our research in the context of psychological concepts of S. Bem through the prism of theories of gender schemes and lenses, namely polarization, androcentrism and biological essentialism, in which the similarity with the findings of L. Vyhotskyi on the mentality of "sign mediation" is traced, when a cultural sign becomes a means of organizing the subjective behavior of an individual during the period of maturing. Socialization ensures the join of a child to the gender culture of society and is the most important factor that determines the design of his/her gender identity, subjective activity in the process of self-creation of the gender "Self" in accordance with the age, the area of the nearest development and the leading activity, new formations in mental development ${ }^{1}$. Shawn Burn describes four stages of gender identity: gender identification (attribution by a child him/herself to a particular gender);

1 Bem S. Sex-role adaptability: One consequence of psychological androgyny. Journal of Personality and Social Psychology. 1975. № 31. Р. 634-643; Выготский Л.С. Собрание сочинений : в 6 т. / под ред. А.Р. Лурия, М.Г. Ярошевского. Москва : Педагогика, 1982. Т. 1. 488 с. 
gender constant (understanding that gender is constant and cannot be changed); differential inheritance (desire to be the best boy or best girl); gender self-regulation (a child him/herself begins to control their behavior, using the sanctions she takes to him/herself $)^{2}$. Supporters of the theory of assimilating gender schemes (S. Bem, V. Haydenko, C. Halverson, C. Martin) see in the primary identity the confirmation of their main postulate that children assimilate and reproduce gender-typical behavior models even before they become able to realize them ${ }^{3}$.

The peculiarities of gender socialization can be interpreted in two ways: both identity acquisition and behavior. The choice of an identification object is based on the sign features of a gender, verbal definition - boy/girl, mother/father, aunt/uncle, the latter of which means to the child not the level of relativeness, but gender affiliation.

Scientists, highlighting the role of adults in gender identification of a child, underline the most important mechanism of imitation of all adults' behavior forms, their stereotypical habits, symbols of "courage" and "femininity", which a child starts including into the plot of games. Among the important determiners of the psychological gender development, the researcher distinguished the following: comfortable family relations, family type (full, incomplete), the role of grandparents in grandchildren upbringing, the presence of elder and younger siblings, same and different gender children.

While grounding the research method we used E. Erikson's conception in which the social identity develops in ontogenesis gradually integrating all the identifications. We view the identification and identity as naturally connected psychological phenomena which are on different levels of personality formation and which can be described as the "process-result', "variability-stability", "continuity-resistance". It's quite natural that such correspondences are not fixed dichotomies however their differentiation is important for discovery of gender identification.

Identification with a role is considered as the ability of a child to imagine $\mathrm{him} /$ herself as being a parent or other important person of his/her gender and to reproduce his/her actions. Motivational mechanism of role identification with parents of the same gender lies in the need of performing gender-typical role in communication with peers, that is in the desire of a child to match the patterns of behavior appropriate to the gender to be accepted by peers and

${ }^{2}$ Берн Ш. Гендерная психология / пер. 3 англ. Санкт-Петербург, 2001. С. 45-52.

3 Гендерна педагогіка: хрестоматія / переклад 3 англ. В. Гайденко, I. Предборської ; за ред. В. Гайденко. Суми : ВТД «Університетська книга», 2006. 313 c.; Martin C., Halverson C. The effects of sextyping schemas on young children's memory. Child Development, 1983. P. 563-574. 
feel yourself competent and confident in their environment. In such conditions parents become important and available model of identification.

Besides stereotypical expectations, parents stimulate activity acceptable for the gender of a child, when they provide their children with clothes and toys specific to their gender. Girl are usually presented with dolls, doll houses and toy furniture. Boys receive cubes, constructor kits, auto models etc. as presents. American psychologists J.-Sh. Hyde and K. Martin stated that boys-preschoolers more often play in gender stereotypical games, when they understand that playing with "girlish" dolls is bad, on their parent's opinion. Adults with the help of their attitude direct boys' and girls' games and activities. For example, a boy playing with dolls is usually ridiculed by others. Adults encourage behavior stereotypes, typical for some gender thus, a boy is ashamed for crying and tears, and a girl is told off for pranking, desire to become a researcher or an inventor, etc. Adults continue to form gender roles with the help of directing both genders onto various kinds of duties: girls tidy the rooms, boys are working in the garden ${ }^{4}$.

\section{Methodology}

When choosing psychodiagnostic tools for the research, the fact that the content of gender ideas of a child is an important indicator of gender-role identity acquision was considered. Gender identity appears in the perspective of motivational-value dispositions of an individual as appropriate to the age of symptom-complex-masculine-feminine properties in the space-time dimension.

The following hypothesis was put forward: that in the preschool years, the acquisition of gender consciousness and self-awareness of children is characterized by a primarily unconscious imitation and reproduction of gender models of the closest social environment (gender-role behavior of the parental family and children's educational institutions).

The main empirical tasks include: exploring the content of children's perceptions of a human as a female/male, family responsibilities and professions, finding out the features of self-esteem and mutual-esteem in the gender-appropriate real and ideal Self, determining the specificity of the influence of parental and pedagogical expectations and the Media direction to the gender behavior of a preschooler.

For the realization of these tasks a complex of modified diagnostic methods was used, such as "Conversation with a child" by N. Plisenko,

\footnotetext{
${ }^{4}$ Hyde J.-Sh. Half the Human Experience: The Psychology of Women. LexingtonMassachusetts-Toronto : D.C. Heath and Company, 1991. 475 p.; Martin C., Halverson C. The effects of sextyping schemas on young children's memory. Child Development, 1983. P. 563-574.
} 
"Features distribution" by M. Ginzburg, the scale of self-evaluation by Dembo-Rubinshtein, "Gender-role identification" by N. Belopolska, methods of a child identification with parents by O. Zakharov, as well as the analysis of children's drawings, participant observation ${ }^{5}$. The observation of children in the conditions of free communication was used in order to study the peculiarities of intergender communication of children in the conditions of real disposition of "gender typical games and toys". We relied on the ideas formulated in the works of V. Kotyrlo, U. Kuzmenko, S. Ladyvir, R. Pavelkiv, Y. Prykhodko, O. Konyanko, T. Pirozhenko, S. Tyshchenko and other scholars to study the psychology of preschoolers, value attitudes of a child, potential opportunities of a preschooler in understanding the moral norms that regulate the intergender relationship, as well as on the principles of experimentally-genetic method by S. Maksymenko, which allowed to conduct their reproduction and modeling in "special (unstereotyped) conditions" $"$. The research concerned the content of the norms on gendertypical qualities of a person (man and woman), family duties and professions according to the parameter "sustainability - flexibility". If the first series of methods directed children to choose the qualities, specific only for a man or only for a woman, the second series allowed them to select "androgyne" qualities that characterize two genders at the same time, as well as the qualities that are not inherent to both male and female representatives. The peculiarities of the self-assessment of boys and girls in the masculinefeminine construct, which were complemented by the expected assessment from parents as "significant others" were defined: "My mother (Dad) thinks that I... am a child".

The total sample consisted of 86 children of 5-7 years old (44 boys and 42 girls) from preschool educational establishments № 36, 25, 27 of Ternopil.

\section{Primary gender representations of children of different ages in the preschool age}

In terms of the content of gender representations of preschool children, three groups of children were distinguished, named: "gender typical", "ambivalent" and "androgynous". The first group consisted of feminine girls and masculine boys (about 64\%), with a dichotomy of knowledge about

${ }^{5}$ Кікінежді О.М. Гендерна ідентичність в онтогенезі особистості : монографія. Тернопіль: Навчальна книга-Богдан, 2011. С. 75-112; Методика діагностики самооцінки Дембо-Рубінштейн (в модифікації A.M. Парафіян). URL: http://psychologis.com.ua/metodika_diagnostika_samoocenki_dembo-rubinshteyn_ modifikaciya_prihozhan.htm.

${ }^{6}$ Максименко С.Д. Генеза здійснення особистості. Київ : Вид-во ТОВ «КММ», 2006. C. 54. 
"feminine" and "masculine" (interests, behavior, character traits, skills, games, toys, occupations, tools, activities, professions etc.), denial of "gender atypical" games ("cars for boys" and "dolls for girls", "boys would break a doll"; "these are not their games because they are not girls"; "not good because all will laugh of them" etc.) and the dominance of categorical, stereotyped judgments, such as: "I don't want to be a girl - they are crybabies, they are insulted by all", "boys are all scoundrels and untidy". The ideas of boys and girls about the image of "ideal children" were complete opposite, as well as identification with persons of the same gender and separation from peers of another gender in interactions (in games, communication, relationships). The number of children with ambivalent ideas regarding gender roles was significantly lower (21\%). This group was characterized by moderate judgments about gender, masculine and feminine features, uncertainty in future family and social spheres of men and women activity. Children demonstrated varying degrees of willingness to emotionally empathize with the other gender in co-operative activities, showing misunderstanding and confusion about choosing gender behaviors in fixed situations, and in replacing toys and games.

The group with "clear egalitarian views" $(15 \%)$ was characterized by a high degree of androgynous behavior, a low-degree stereotyping of judgments regarding gender roles, features, occupations, responsibilities, etc. These children showed psychological readiness to interact with peers of both their own and other genders, emotional empathy in gender mixed interaction, were willingly engaged in both "gender-typical" and "atypical" classes: "Men have got cars, and I also want to have one...", "Mom and sister make small dumplings, and I, as a boy, make big ones..."; "Girls also play football". In the artificially created situations of the shortage of "boyish" toys, the boys involve themselves into "girlish" activities, although they had no great desire to play dolls. Such boys and girls are more strongly identified with atypical family and social roles $(\mathrm{t}=0.30$ at $\mathrm{p}<0.01)$, which is primarily due to the influence of parental families built on the interchangeability of marital responsibilities, skills. The participant observation and evaluations of the experts showed the same behavior and psychological characteristics of boys and girls of this group, their lesser conflict willingness. Although boys prefer gaming competitions, rivalries, initiative, and girls prefer games of care and service, their intergender relations have been more emotionally warm, sincere, full of variety of joint activities.

In general, gender perception of polarization of the preschoolers of both genders are dominated by, with a focus on "gender-typical" and moral qualities in the ideal image of a "man" and a "woman": $53 \%$ of girls and $42 \%$ of boys showed caring, help and support $-47 \%$ and $44 \%$ respectively, determination and courage $-46 \%$ of girls and $54 \%$ of boys. The content of 
the cognitive component (psychological portrait of a "real" man/woman, boy/girl) as model standards was similar in both genders. However, the slightly higher stereotyping of the male gender image is more characteristic of boys, while the "female" and "male" worlds were equally interesting for girls $(r-0.40$ at $p<0.01)$. Both boys and girls are more strongly identified with family and social atypical roles that are not typical for their own gender $(\mathrm{t}=0.30$ at $\mathrm{p}<0.01)$, which is due to the influence of the parental family, which is built on the interchangeability of marital responsibilities, and skills (table 1).

According to the boys' perceptions, the first five qualities of the masculine image are typically masculine: strength, courage, rudeness and anger, determination, intellect. Next are gender-neutral features (politeness, courtesy, being hardworking, laziness, caring, restraint). The image of a woman in boys' views also turned out to be traditional (feminine characteristics were found in their rating: tenderness, tearfulness, weakness, cowardice and kindness). Gender-neutral features of a woman were such as neatness, beauty, obedience, caring, restraint.

Table 1

Gender images in the perceptions of preschool boys

\begin{tabular}{|c|c|c|c|c|c|}
\hline № & Image of a man & in \% & № & Image of a woman & in \% \\
\hline 1 & Strong & 100 & 1 & Affectionate & 94.4 \\
\hline 2 & Brave & 100 & 2 & Whiny & 94.4 \\
\hline 3 & Rude, angry & 94.4 & 3 & Weak & 77.7 \\
\hline 4 & Determined & 72.2 & 4 & Cowardly & 77.7 \\
\hline 5 & Smart & 66.6 & 5 & Kind & 72.2 \\
\hline 6 & Polite & 61.1 & 6 & Neat & 61.1 \\
\hline 7 & Hardworking & 55.5 & 7 & Beautiful & 61.1 \\
\hline 8. & Lazy & 50 & 8 & Obedient & 61.1 \\
\hline 9 & Caring & 50 & 9 & Caring & 55.5 \\
\hline 10 & Reserved & 44.4 & 10 & Reserved & 44.4 \\
\hline 11 & Obedient & 44.4 & 11 & Hardworking & 44.4 \\
\hline 12 & Handsome & 44.4 & 12 & Polite & 38.8 \\
\hline 13 & Neat & 38.8 & 13 & Lazy & 38.8 \\
\hline 14 & Persistent & 38.8 & 14 & Persisten & 33.3 \\
\hline 15 & Unwise & 33.3 & 15 & Smart & 33.3 \\
\hline 16 & Kind & 27.7 & 16 & Unwise & 22.2 \\
\hline 17 & Weak & 16.6 & 17 & Determined & 22.2 \\
\hline 18 & Whiny & 11 & 18 & Rude, angry & 11 \\
\hline 19 & Cowardly & 11 & 19 & Brave & 5.5 \\
\hline 20 & Affectionate & 5.5 & 20 & Strong & 0 \\
\hline
\end{tabular}


Table 2 clearly shows that in the perceptions of girls, the first five characteristics in a male image (strength, courage, laziness, rudeness and anger, intellect) are masculine, and in the female image - feminine (neatness, tearfulness, beauty, obedince, caring). A third of girls deny masculine features in female images.

Table 2

Gender images in the perceptions of preschool girls

\begin{tabular}{|c|c|c|c|c|c|}
\hline № & Image of a man & in \% & № & Image of a woman & in \% \\
\hline 1 & Strong & 100 & 1 & Neat & 100 \\
\hline 2 & Brave & 76.5 & 2 & Whiny & 88.2 \\
\hline 3 & Lazy & 70.6 & 3 & Beatiful & 88.2 \\
\hline 4 & Rude, angry & 64.7 & 4 & Obedient & 82.4 \\
\hline 5 & Smart & 64.7 & 5 & Caring & 82.4 \\
\hline 6 & Determined & 53.9 & 6 & Affectionate & 82.4 \\
\hline 7 & Unwise & 47.1 & 7 & Weak & 70.6 \\
\hline 8 & Kind & 41.8 & 8 & Cowardly & 70.6 \\
\hline 9 & Weak & 35.3 & 9 & Kind & 70.6 \\
\hline 10 & Cowardly & 35.3 & 10 & Polite & 70.6 \\
\hline 11 & Reserved & 29.4 & 11 & Hardworking & 58.8 \\
\hline 12 & Polite & 29.4 & 12 & Smart & 47.1 \\
\hline 13 & Caring & 29.4 & 13 & Persistent & 35.3 \\
\hline 14 & Obedient & 29.4 & 14 & Unwise & 35.3 \\
\hline 15 & Persistent & 29.4 & 15 & Reserved & 35.3 \\
\hline 16 & Reserved & 29.4 & 16 & Rude, angry & 29.4 \\
\hline 17 & Handsome & 23.5 & 17 & Brave & 29.4 \\
\hline 18 & Affectionate & 23.5 & 18 & Lazy & 29.4 \\
\hline 19 & Whiny & 11.8 & 19 & Determined & 23.5 \\
\hline 20 & Neat & 11.8 & 20 & Strong & 5.9 \\
\hline
\end{tabular}

It has been found out that, at preschool age, the features of gender identification depend on the object of identification and are determined by the subject of identity in the process of his/her imitation due to two mechanisms of simple reproduction (imitation) and to different extent conscious modeling (acceptance) of sign attributes of gender and, first of all, external (physical) and character (psychological and behavioral) signs of "masculine" and "feminine", verbal presentation and self-presentation, categorization and self-categorization. The emotional-evaluative component of gender identity development is characterized by the similarity of content of value-positive self- and mutual attitude in boys and girls with minor differences in the evaluation of predominantly physical features: boys consider themselves to be physically stronger and girls - more active. It was found that the increase in gender-typical orientations in boys and girls is due 
to a lower involvement of the former and higher ones of the latter in doing chores (36.4\%: $51.1 \%$, respectively).

The behavioral component of gender consciousness is characterized by the fact that boys prefer competitive games, rivalry, domination, girls, on the other hand, games of caring and service. Thus, according to our study, $54.5 \%$ of boys and $44.7 \%$ of girls prefer games with persons of the same gender; $39.4 \%$ and $45 \%$ respectively enjoy joint, gender-mixed games. While $10.6 \%$ of girls prefer playing with boys, only $6.1 \%$ of boys choose girls for joint games, which may be the evidence of greater sociability and egalitarian behavior of girls.

\section{Social sources of influence on preschoolers' gender views}

Among social sources of influence on the gender ideas of preschoolers are the parental family, educational institutions, the contents of books, magazines, entertainment, toys, games, etc. Features of intergender interaction depend on the choice of toys, games, activities, especially "gender-typical". In particular, children of both genders categorically denied playing boys with dolls: "boys should only play cars", "they break the doll"; "these are not their games because they are not girls"; "it is not good, because all will laugh of them", "boys are not girls"; "it's a shame because boys have their own toys". Preschoolers answered similarly regarding girls playing cars. Among the arguments were the following: "because girls are not boys", "cars are boys' toys because girls have dolls", "cars are only for boys". In few answers was mentioned that girls could play cars, but only with the one that can be "constructed".

In general, polarization of preconceptions about psychological properties of the genders in preschoolers dominated: "gender-typical" features in the image of a "man" and a "woman" prevail. Boys and girls consider kindness to be typical of both man and woman ( $47 \%$ and $44 \%$ respectively), caring (53\%:42\%) and bravery (46\%:54\%). These children also showed a high level of stereotyped views on male and female professions, with differentiating professions by gender by the majority of boys $(72.7 \%)$ compared to girls (70.2\%) (fig. 1). 


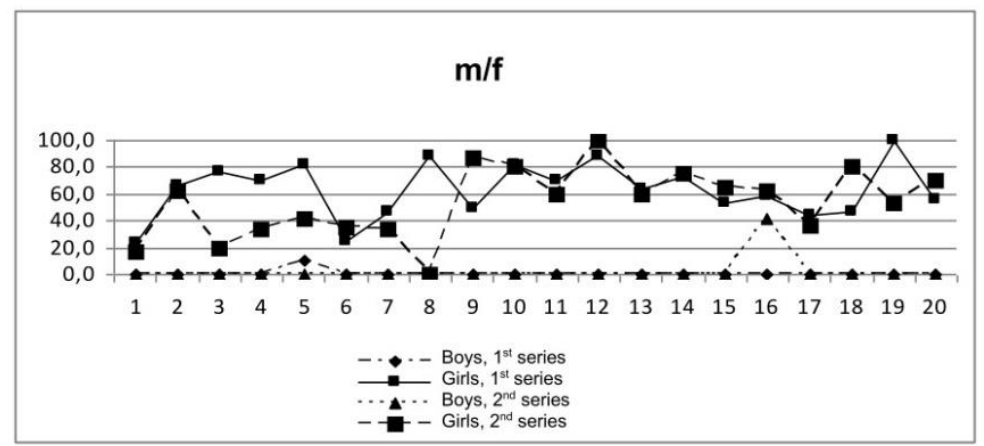

Figure 1. Gender profile of male-female features in boys and girls' perceptions (in \%)

Note: features - strength (1), weakness (2), rudeness (3), affection (4), tearfulness (5), restraint (6), courage (7), cowardness (8), diligence (9), laziness (10), intellect (11), stupidity (12), kindness (13), anger (14), neatness (15), politeness (16), caring (17), beauty (18), compliance (19), determination (20).

Preschoolers also demonstrated a high level of stereotyped views on male and female professions (the profession of an educator (64\%), a hairdresser $(54 \%)$, a caretaker (50\%), a babysitter (64\%), a librarian (50\%) are considered as typically female). In the rating of typically male ones, $80 \%$ of preschool children indicated the following professions: an electrician, a carpenter, a fireman, a football player, a builder, a priest, a pilot, a military, a policeman, a businessman, a president, an astronaut, a banker, a chauffeur, etc. Typical for both men and women turned out to be professions of a doctor $(82 \%)$, an artist $(70 \%)$, a cook $(62 \%)$, for half of the respondents (54\%) the profession of a bartender and a chief manager. Among those who differentiate professions by gender - most are the boys (72.7\%) in comparison with girls (70.2\%) (fig. 2).

Identification with an adult from the closest social environment is found to be a leading psychological mechanism $(87 \%$ of boys and $88 \%$ of girls want to look up to their gender appropriate adults, primarily parents), significantly fewer (about $13 \%$ of boys and 12\% of girls) are identified with the parent of the other gender ( $p<0.05$ ), which can be explained by the emotionally significant closeness of boys to a mother, the participation of a father in the upbringing of a girl. 


\section{$\mathrm{m} / \mathrm{f}, \%$}

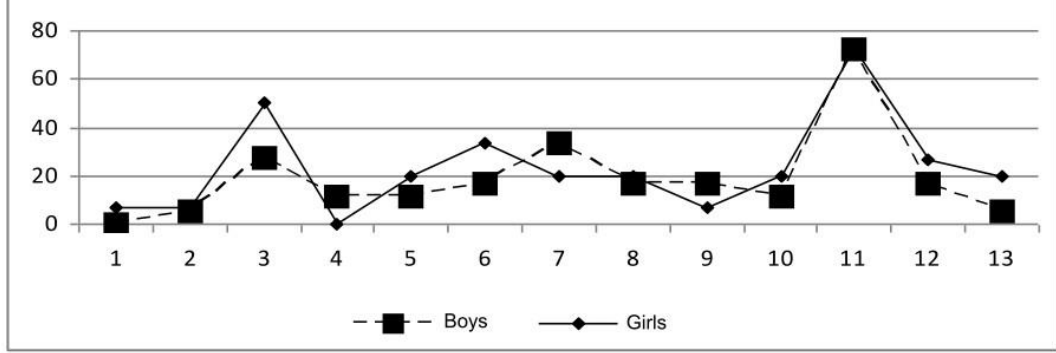

Figure 2. Male-female responsibilities according to boys' and girls' perceptions (in \%)

Note: 1 -car repairing, 2 - furniture repairing, 3 -taking out the garbage, 4 - electrical appliances repairing, 5 -furniture moving (in a flat), 6 -digging garden, 7 - do the washing-up, 8 - tiding the room, 9-washing (laundry), 10 - ironing, 11 -do the shopping, 12 - cooking, 13 -clothes mending.

It has been found that identification with the gender roles of parents (their family and professional responsibilities) becomes a motivational mechanism as a condition of gender-similarity with parents of one or another gender, which significantly broadens the range of preconceptions about the social status of the genders. Higher self-identity level with mother compared to father was found in girls $(36.1 \%)$. The boys' answers were evenly distributed between the two options: "with mom" and "with dad". $17 \%$ of girls and 3\% of boys indicated equal participation of both parents in the interaction with them.

The older preschooler pays attention mainly to the peculiarities of the behavior that is "appropriate" to his/her gender and does not show interest in gender-non-typical behavior. At this age, children begin to evaluate their personality for gender conformity (they are disciplined in this way by their parents and "significant others"), opposing their own preferences, attitudes, behaviors, features, relationships to the other gender. Thus, gender conformity becomes a prescription of standard behaviors for boys and girls. It is the internalization, as the most important socio-psychological mechanism of identification in the process of development of the gender image of a preschooler, that serves as a "starting point" for the design of "internal", motivational vision of "female" and "male". As the child grows older, preconditions about gender roles become filled with moral content that weakens the polarization of boys' and girls' behavior. 
We confirmed the conclusions of T. Hovorun, R. Pavelkiv, Y. Prykhodko, I. Shulha and other scientists about the dominance of gender stereotyped ideas of preschoolers about masculinity and femininity, the beginnings of the dichotomy of choice of their friends, classes, toys and games, types of activity, interests, preferences, professions, etc. The mechanism of such reproduction of the comprehended in the process of imitation socio-cultural norms of femininity-masculinity is a prerequisite for future juxtaposition and confrontation of genders in traditional gender orientations. In general, in $53.2 \%$ of girls and $36.2 \%$ of boys value-positive attitude towards themselves as carriers of their genders predominate. Most boys $(80.6 \%)$ rate the behavior of girls as more positive than their own.

In the ideal Self the male (dad's) adult world was found to be more tolerant, meaningful, attractive and referential for both genders, and boys attribute it to the ideal one ( $<<0.05)$, whereas for girls, both parents are the role model $(\mathrm{p}<0.05)$. Higher stereotyping of the male gender image is more typical of boys, while the feminine and masculine worlds are equally attractive to girls $(\mathrm{r}-0.40$ at $\mathrm{p}<0.01)$. The coincidence of self and mutual evaluative attitudes towards moral qualities indicates the dominance of orientation towards gender-neutral behavior, which is an important prerequisite for the actualization of androgynous principles. Integration as a "chaining" of "masculine" and "feminine" in the gender consciousness acts as an identifying core of gender behavior, which can be interpreted as an egalitarian value benchmark.

Since the main way of assimilating gender role is to identify oneself with a relative of the same gender, imitation and following become the leading psychological mechanisms. Significantly fewer children (13\% of boys and $12 \%$ of girls) identify themselves with the parent of the other sex $(p<0.05)$, which can be explained by the boys' emotionally significant closeness to the mother and the father's involvement in the girl's upbringing. The identification of children with parental gender roles, above all their family and professional responsibilities, is the result of categorization and selfcategorization and reproduction. A higher level of self-identification with mother than with father was found in $36.1 \%$ of girls. Androgynous identification is characterized by a uniform distribution between two ideals: "to be like a mom" and "to be like a dad".

The results of the study confirmed the conclusions of the works of Sh. Bern, V. Haydenko, T. Hovorun, I. Kon, R. Pavelkiv, Y. Prykhodko, $\mathrm{V}$. Kuzmenko and others as to the formation of primary gender identity in most children by the end of the preschool age, as well as the relationship between the relatives of the identical gender and the emotional attitude to $\mathrm{him} / \mathrm{her}$ in the process of interaction with him/her. Perceptions of gender roles are becoming filled with increasing moral content that weakens the 
polarization of boys and girls' behavior. In general, pre-school boys were found to be more stereotyped than girls.

In the process of identifying a child with "gender-typical" attributes toys, activities, fairy-tale characters' behavior, etc., as a result of real imaginary actions, these or other desirable features of "gender-appropriate" behavior are acquired, thus enriching the image of the "Self", filling up with new changes. The identity of girls and boys in traditional gender socialization is filled with polarized content, while in the alternative, egalitarian one, there is variability and diversity.

In preschool age there is a further deepening of the differentiation of the cognitive ideas of six-year-olds about the psychological differences of the genders; the beginnings of reflections on the prospects of one's future professional, educational, and family life emerge, as evidenced in the choice and content of the role-playing games. It is revealed that the vast majority of girls $(89.4 \%)$ and boys (84.9\%) enjoy playing games together, preparing for the holidays, competitions, etc. Most girls (55.3\%) and boys (63.6\%) said that it was much better and more fun to play with other gender children in shared toys and fun activities. However, $42.6 \%$ of girls and $36.4 \%$ of boys prefer playing their gender games. In an imaginary situation, such as "If Buratino were a girl, what toys would he choose" - girls preferred dolls (wooden, large), pyramids, cubes, mosaics, cars. Boys preferred cars, constructor kits, cubes, mosaics, dolls, wooden soldiers. Consequently, children of both genders in the (imaginary), atypical for their gender situation, allow more variety of toys choice for a fairy-tale character (i.e., differentiate between typically girlish and boyish toys) than in real interaction with one another.

It has been found that both genders ( $89.4 \%$ of girls and $84.9 \%$ of boys) enjoy playing games together, preparing for the holidays, competitions, etc. In the process of identifying a child with gender-typical objects, toys, fairytale characters, etc., as a result of the imaginary action, he or she acquires certain desirable features of objects of gender behavior, the image of the "Self" is enriched with the new gender (moral) content.

It is possible to state the fact of assimilating gender stereotyping by children rather early, which is explained by the psychological patterns of greater orientation of children to their gender. A quantitative and qualitative analysis of the content of children's perceptions of masculinity-femininity and family roles has shown that they reflect the socially-approved standards of femininity-masculinity prevalent in the immediate social environment. At the same time, it must be acknowledged that these ideas are poor, schematic, fragmentary. The roles of preschoolers in story games is a reflection of the traditional expectations of adults: the interests of boys are mainly focused on equipment, competitive, sports, outdoor games, pursuit of victory, 
leadership. The interests of girls are more focused on interpersonal relationships, caring and emotional sphere of activity. The above points to the important role of the phenomenon of "genderization" in the daily life of a child, as a factor in the "beginning of gender bias", which further leads to gender differentiation of roles and responsibilities.

\section{CONCLUSIONS}

The sociocultural situation of the development of the gender consciousness of a preschool child raises the dilemma of traditional and egalitarian orientations and behaviors in assimilation of gender roles, since it depends on the content of gender orientations. Three groups of gender identity varieties have been identified in preschoolers: gender-typical, ambivalent and androgynous. Uniformity in the content of gender images of the real and the ideal Self in the representatives of both genders involves the integration of feminine-masculine and gender-neutral (moral) qualities, which can indicate the preservation of the internal position of a child (preschooler) and the formation of a new social position - the status of a schoolboy/schoolgirl.

In the context of a "gender" society, based on the biological gender of the individual, appropriate gender-role categorization and self-categorization of children and adults are carried out, which determines the specificity, content and context of primary gender socialization; prerequisites for gender self-determination of the growing personality are created, which results in the assimilation of cultural gender-appropriate norms, stereotypes and imitation of the expected standards, which become internal regulators of the social activity of the individual.

Imitating a gender appropriate adult is a major way of internalizing children in the preschool group with gender roles. Orientation of children to stereotyped patterns of male and female behavior enables the child to distinguish the behavior of one's own gender from that of another. The findings suggest that the acquisition of gender identity as a construct of femininity-masculinity-androgyny has a different content in boys and girls: more dichotomous in the former, more flexible in the latter, which can be explained by the broader norm of female behavior compared to the masculine behavior. Therefore, egalitarian views and manifestations of androgynous behavior begin to form more earlier in the self-consciousness of girls than in boys. As for the behavior of boys, the closest surroundings remain more stereotyped, more violent, dominant.

The revealed absence of significant differences in the masculinityfemininity indices in boys and girls self-esteem indicates, in our view, to the unification of gender roles, with a slight tendency for the prevalence of 
femininity in girls and the index of masculinity in boys that, in general, causes the beginning of gender deferentiation in this age.

\section{SUMMARY}

The article deals with the psychological and pedagogical factors of gender socialization of preschoolers in Ukraine.

The specificity of the process of gender socialization and identification at preschool age lies in the assimilation of the represented adult prescriptions, the accumulation of the child's personal experiences and values related to gender, which acquire personal meaning and become a standard of gendered behavior: feminine, masculine or androgenius. The imposition of traditional gender roles interferes with the development of androgynous properties of children, the development of their commonwealth, the positive Self-image. Three groups of gender identity varieties have been identified in preschoolers: gender-typical, ambivalent and androgynous.

Specific phenomenon of the preschool age is the acquisition of genderrole identity as a fragmentary and mosaic gender image of the desired Self (personal construct of the "real" girl/"real" boy), which activates the representation of the feminine-masculine and moral qualities by a child both on nominative, and awareness levels, as the subject of gender behavior dichotomous, ambivalent or androgenic.

Parenting behavior is the first gender role model that boys and girls are identified with. The findings suggest that the social environment does not fully meet the needs of children that are important for the development of gender self-esteem at preschool age, which, in turn, negatively affects the formation of the child's internal position, since gender socialization develops predominantly at the micro-level in one direction (to either dominant or egalitarian models).

The overwhelming majority of the parental family is not a model of gender equality and interchangeability; rather, it is an example of double female employment and remote parenting. Children choose from a variety of possible human characteristics only those identified in the culture as acceptable to her/his gender. The self-concept becomes gender-typical and the two genders are perceived differently not so much in terms of physical, morphological properties but as in personal qualities. It is the internalization, as the most important socio-psychological mechanism in the development of the gender image of the preschooler, that serves as a "starting point" for the design of the "inner" vision of "female" and "male". As the child grows older, the perception of gender roles is filled with moral content that weakens the polarization of boys and girls' behavior. 


\section{REFERENCES}

1. Берн Ш. Гендерная психология / пер. 3 англ. Санкт-Петербург, $2001.456 \mathrm{c}$.

2. Выготский Л.С. Собрание сочинений: в 6 т. / под ред. А.Р. Лурия, М.Г. Ярошевского. Москва : Педагогика, 1982. Т. 1. 488 с.

3. Гендерна педагогіка : хрестоматія / переклад з англ. В. Гайденко, I. Предборської ; за ред. В. Гайденко. Суми : ВТД «Університетська книга», 2006. 313 с.

4. Говорун Т.В., Кікінежді О.М. Гендерний дискурс в психологічній науці та педагогічній практиці. Психологічний часопис : збірник наукових праць / за ред. С. Д. Максименка. Київ : Інститут психології ім. Г. Костюка НАПН України, 2016. Вип. 3. № 1 (3). C. 41-55. URL: https://doi.org/10.31108/1.2018.10.20.

5. Кікінежді О.М. Гендерна ідентичність в онтогенезі особистості : монографія. Тернопіль : Навчальна книга-Богдан, 2011. 400 с.

6. Кікінежді О.М., Говорун Т.В., Шульга І.М. Гендерне виховання дошкільнят : навчально-методичний посібник. 2-ге вид., допов., перероб. Тернопіль : Навчальна книга-Богдан. 2015. 192 с.

7. Кон И.С. Ребенок и общество : учебное пособие для студ. высш. учеб. заведений. Москва : Издательский центр «Академия», 2003. 336 с.

8. Кіммель М. Гендероване суспільство. Київ : Сфера, 2003. 490 с.

9. Максименко С.Д. Генеза здійснення особистості. Київ : ТОВ «КМM», 2006. $240 \mathrm{c.}$

10. Павелків Р.В. Вікова психологія : підручник. Київ : Кондор, 2011.469 c.

11. Приходько Ю.О. Нариси становлення та розвитку дитячої психології : навчальний посібник для вищих навч. закладів. Київ : НПУ ім. М.П. Драгоманова, 1999. 205 с.

12. Bem S. Sex-role adaptability: One consequence of psychological androgyny. Journal of Personality and Social Psychology. 1975. № 31. P. 634-643.

13. Erikson E. Childhood and Society. New York : W.W. Norton\&Company, 1963. 445 p.

14. Hyde J.-Sh. Half the Human Experience: The Psychology of Women. Lexington-Massachusetts-Toronto : D.C. Heath and Company, 1991. 475 p.

15. Kikinezhdi O.M., Vasylkevych Ia.Z. The problem of personal selfrealization of Ukrainian youth in European integration: gender aspect. Advanced trends of the modern development of psychology and pedagogy in European countries: Collective monograph. Riga: Izdevnieciba "Baltija Publishing", 2019. P. 184-201.

16. Maccoby E.E., Jacklin C.N. The Psychology of Sex Differences. Stanford, CA : Stanford University Press, 1974. P. 391. 
17. Martin C., Halverson C. The effects of sextyping schemas on young children's memory. Child Development, 1983. P. 563-574.

18. Martin K. Becoming A. Gendered Bodies: Practices of Preschools. American Sociological Review. 1998. Vol. 63. № 4. P. 494-511

\section{Information about the authors:}

Kikinezhdi O. M.,

Doctor of Psychology, professor,

Head of the Psychology Department, Director of the Scientific Research Centre of the Problems of Gender Education and Upbringing Pupils and Students of National Academy of Educational Sciences of Ukraine, Ternopil Volodymyr Hnatiuk National Pedagogical University, 2, M. Kryvonosa str., Ternopil, Ukraine ORCID ID: orcid.org/0000-0002-9240-279X

Vasylkevych Ya. Z., Ph.D. in Psychology Sciences, Associate Professor of the Psychology Department State Higher Educational Institution "Pereyaslav-Khmelnytsky Hrihoriy Skovoroda State Pedagogical University" 30, Sukhomlynsky str., Pereiaslav-Khmelnytskyi, Ukraine ORCID ID: orcid.org/0000-0002-5946-3005 